\title{
Pest resistance feared as farmers flout rules
}

Tom Clarke, London

Nearly one-fifth of farmers in the US midwest are ignoring federal rules about how much transgenic maize (corn) they can plant, according to government figures. Experts fear that this non-compliance could encourage insects to develop resistance to the insecticide produced by the crop.

Some transgenic maize contains a gene from the bacterium Bacillus thuringiensis $(B t)$, which allows the corn to produce a natural insecticide. Under rules laid down by the Environmental Protection Agency, farmers who plant $B t$ maize must devote $20 \%$ of their acreage to non- $B t$ varieties. These 'refuge' areas should prevent pests from developing resistance to the insecticide, as resistant insects will breed with susceptible insects living in the refuge and dilute the trait.

But a study released last month by the Center for Science in the Public Interest (CSPI), a Washington-based pressure group, reveals that this rule is being ignored. The report describes data from the US Department of Agriculture showing that last year $19 \%$ of all $B t$ maize-growing farms in Iowa, Minnesota and Nebraska failed to plant the necessary refuges. No refuge at all was planted on $13 \%$ of the farms.

Most farms that broke the rule were small, planting less than 80 hectares (200 acres) of $B t$ maize. Farms of this size are not monitored by the Agricultural Biotechnology Stewardship

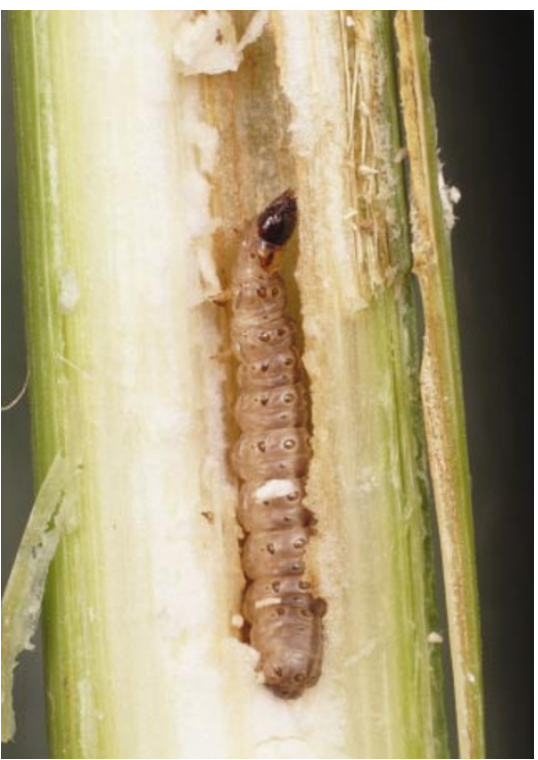

$B t$ maize is resistant to the European corn borer.

Technical Committee, the industry body that monitors growing practices.

"It's just a matter of time before resistance develops," warns the report's author Gregory Jaffe, director of biotechnology projects at the CSPI. Bt maize will be rendered useless, adds Jaffe, if pests such as the European corn borer, the chief target of transgenic maize, develop resistance.
But transgenic-crop firms disagree. "This won't jeopardize the long-term effectiveness of the technology," says Eric Sachs, director of scientific affairs at biotechnology company Monsanto, based in St Louis, Missouri. Those ignoring the rules grow just $5 \%$ of $B t$ maize planted in the three states, he says.

Only $25 \%$ of maize grown in the midwest contains $B t$, and the likelihood that noncompliance from a fraction of these farms will lead to resistance is small, agrees insect ecologist Bruce Tabashnik at the University of Arizona in Tucson. "It's unlikely that there is sufficient pressure on the insects," he says. In seven years of academic field surveys, insects resistant to $B t$ maize have not been documented in the United States, Tabashnik adds.

But this could change. New Bt maize, developed by Monsanto and designed to control a root pest, the maize rootworm, is due to be sown next year, and is expected to be adopted far more widely than existing $B t$ varieties. "Although non-compliance may not be an immediate hazard, it could lead to a serious problem in the future," says Tabashnik.

The transgenic-crop developers maintain that small farms won't pose a major problem - but they are concerned. "It's not clear that we have a problem of biological significance," says Val Giddings, vice-president for food and agriculture with the US Biotechnology Industry Organization, "but we do have a problem of regulatory significance.”

\section{Europe finds transgenic food hard to swallow}

\section{Jim Giles, London}

Transgenic food is unlikely to appear on European tables soon, analysts say despite a vote by the European Parliament that opens the way for European nations to declare currently unlicensed varieties of the foods safe to eat.

On 2 July, the parliament passed a measure that would require food with $0.9 \%$ or more of genetically modified content to be labelled as such. Transgenic ingredients will have to be traceable to the farm on which they were grown.

The measure, which is expected to be approved by the Council of Ministers in the next few weeks and pass into law, should open the way for the approval of new varieties of transgenic crops.

About 20 varieties, including insecticideand herbicide-resistant maize (corn), are currently awaiting approval by the European Union (EU). The process has been blocked by countries such as France and Germany, creating a de facto moratorium. They and others are expected to drop their opposition now that the new rules are agreed.

But even if the approvals process opens up, trade analysts say that sales are likely to be slow. Consumer surveys suggest that European shoppers won't buy food that is labelled as containing transgenic material, and several leading supermarket chains have refused to stock it and are expected to continue to do so.

Trevor Young, an agricultural economist at the University of Manchester, has analysed how much money consumers would need to save for them to buy transgenic crops. He says that no thorough trial has been conducted, but that preliminary studies by him and colleagues suggest that a reduction of around $40 \%$ would be needed. The cost savings associated with transgenic agriculture are unlikely to produce such big discounts.

US farmers' groups have also complained that the cost of implementing the EU's traceability rules will price their transgenic crops out of the market.

The European Parliament's vote was partly intended to stave off a pending US

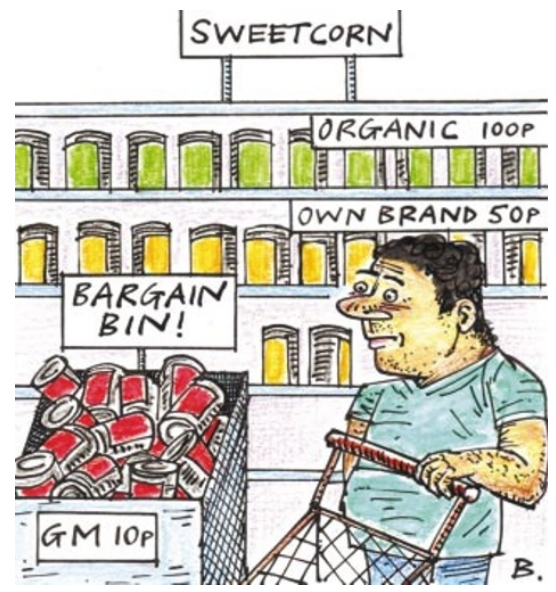

claim to the World Trade Organization (WTO) that EU restrictions on the sale of transgenic food are illegal (see Nature 423, $369 ; 2003$ ). But US officials gave no indication that the case, which some observers interpret as a warning to nations outside Europe, including larger grain importers in Asia, will be dropped. 